Western University

Scholarship@Western

Department of Economics Research Reports

Economics Working Papers Archive

1988

Ocean Freight Rates and Productivity, 1740:1913: The Primacy of Mechanical Invention Reaffirmed

C Knick Harley

Follow this and additional works at: https://ir.lib.uwo.ca/economicsresrpt

Part of the Economics Commons

Citation of this paper:

Harley, C Knick. "Ocean Freight Rates and Productivity, 1740:1913: The Primacy of Mechanical Invention Reaffirmed." Department of Economics Research Reports, 8802. London, ON: Department of Economics, University of Western Ontario (1988). 
RESEARCH REPORT 8802

\title{
OCEAN FREIGHT RATES AND PRODUCTIVITY, 1740-1913: THE PRIMACY OF MECHANICAL INVENTION REAFFIRMED
}

\section{Knick Harley}

\author{
Department of Economics \\ University of Western Ontario \\ London, Ontario, Canada \\ N6A 5C2
}

March 1988

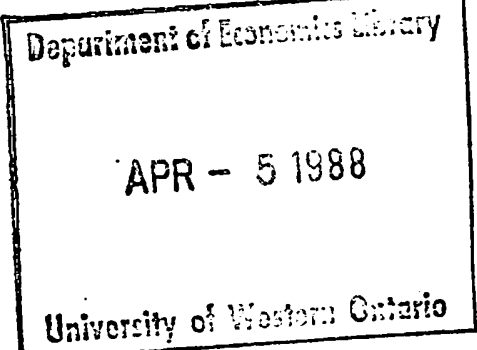


OCEAN FREIGHT RATES AND PRODUCTIVITY, 1740-1913:

THE PRIMACY OF MECHANICAL INVENTION REAFFIRMED

by

C. KNICK HARLEY

Department of Economics,
University of Western Ontario.
March, 1988

This paper should not be quoted without the author's permission.

I have gained insights into this topic as a result of presentations at Queen's University, Kingston, at the University of California at Berkeley, at Stanford University and at the 1987 annual meeting of the social science History Association. I appreciate this help but all errors that remain are my responsibility. Financial assistance of the Social Science and Humanities Research Council of Canada is gratefully acknowledged. I owe a particularly heavy debt to Mrs. S. Pearson who performed the various calculations necessary to construct the various time series of freight rates that underlie this paper. 
Transportation cost reductions both on land and at sea caused by improved mechanical engineering and metallurgy have long been considered key impacts the Industrial Revolution. However, modern research on railroads and on ocean freight rates has cast doubts on this proposition. Douglass North's research on ocean shipping some twenty years ago revealed rapidly declining freight rates during the eighteenth and first half of the nineteenth century but concluded that they were not caused by the technology of the Industrial Revolution. These conclusions have been widely accepted and applied in general work on the nineteenth century economy. 1 This consensus seems to be incorrect. New series on freight rates utilize based on evidence than North's reaffirm that new technology caused freight decline.

Analysis of technological change in the early nineteenth century is central to an understanding of the transformation of the western economies that began about that time. This requires a thorough understanding of the technologies and the markets facing individual industries. The predominant recent view is that technological change was widely diffused and growth was broadly balanced among sectors of the economy. This is somewhat at variance with older views that had emphasized changes in a few sectors-textiles, iron, prime movers and transportation. In the past few years some reassessment of the now prevailing view has suggested that change was more narrowly based than the 
predominant view suggests. ${ }^{2}$ Reexamination of ocean transportation yields results consistent with a view of more narrowly based change in the early nineteenth century.

A very substantial proportion of our knowledge of shipping in the eighteenth and nineteenth centuries comes from studies undertaken by Douglass North and his students $^{3}$. These studies revealed declining freight rates and increasing productivity from the eighteenth to the twentieth century. The sharpest increase in productivity occurred in the first half of the nineteenth century before metal hulls or steam propulsion had a major impact on the Atlantic shipping North studied. He sought to determine "the extent to which technical changes in shipping and in ship construction account for" productivity improvement. He observed, correctly, that the technology in use on the North Atlantic before the American Civil war had been developed by the Dutch prior to 1600 and so its invention, as opposed to its application, played no important role in the nineteenth century. He was then faced with the need to explain the slow diffusion of this technology and the concentration of its impact some two centuries after its development. He attributed the long diffusion to "the decline of piracy and privateering and the development of markets and international trade." Broader evidence and reassessment of North's evidence substantially modifies this conclusion. The decline in American export freight rates before the Civil War reflected special circumstances 
in the shipment of raw cotton and cannot be generally applied to ocean shipping .

North's freight rate series along with a newly constructed series reflecting freights earned by British shipping on older trades, both deflated by an approximation of a British GNP deflator are presented in Figures 1.4 The new series contrasts sharply with North's freights. These British data show freights falling considerably less between the mid eighteenth century and the beginning of the twentieth century. Furthermore, they place the sharp decline in ocean freight after rather than before the $U$. $S$. Civil War. More detailed examination suggests these new series are more accurate reflections of shipping productivity than were North's. Analysis of the decline in freight reasserts that mechanical and metallurgical advances of the Industrial Revolution had special impact on transportation costs.

\section{[Figures 1 about here]}

I. British Freight Rates, $1740-1860^{5}$

Data from the most important British shipping routes permit the construction of a new series of freight rates for late eighteenth and nineteenth centuries. The freight rates on Tyne coal shipped to London ${ }^{6}$ is available on a practically continuous annual basis from 1741 until the First World War from the records of Greenwich Hospital, 
Parliamentary Reports, newspaper quotations and company records. It is also possible to construct almost as Iong and continuous series for freights on timber and grain from various Baltic sea ports from similar sources. This Baltic series starts with ten years beginning in 1757, continues for the 23 years ending in 1800 and then, with a few gaps at mid century, continues until the First World War. The third long series begins in 1810 and provides information on timber imports from British North America. Somewhat inferior information about grain freights from the Black Sea are available for the early 1820 s and then continuously from 1840. Around mid-century information for $U$. $S$. grain exports becomes available. Fortunately, the overall trends of the long series are broadly similar so that an overall index is not overly dependent on the weighting adopted for aggregation (see Figure 2). The index presented in Figure 1 is in its early years an equally weighted average of indices of the coal, Baltic and British North American timber freights available in each year. It is scaled to approximate the rate in shillings per ton on coal from the Tyne to London. As the grain rate from odessa and from New Yory become available they are added to construct the series to 1870. Thereafter the Isserlis index 7 is used. Isserlis's index conforms well to the various partial indices I have constructed and I have not yet undertaken the construction of an alternative. These data are, of course, far from perfect, particularly in the early years 
and must be used with care. The deflation proceedure during the eighteenth century and particularly across the Napoleonic Wars is particularly weak. Considerable confidence seems warrented in the general trend nonetheless.

[Table 1 and Figure 2 about here]

This equally weighted index seems a reasonably approximation of the employment of British shipping in the early nineteenth century. Table 1 presents the estimate of shipping employed in British trade presented by G. F. Young to the select Committee on ...the Commercial Marine in 1844.8 These estimates, despite the considerable imprecision that they involve, clearly indicate the importance of the coastal coal, Baltic, and British North American trades for which freight rate series are available. These trades employed over half of British shipping. This breath of coverage, the absence of any evidence of special circumstances in any of these trades, and the similarity of the trends in the independent series generate considerable confidence in this aggregate series despite its divergence from North's series for American freights.

The most immediately striking feature of the long term series of freight rates is the impact of eighteenth century war time conditions. The peaks in the series correspond to the War of the Austrian succession (1740-48), the seven Years War (1756-63), the War of American Independence (1776-1783) and the wars of the French Revolution and 
Napoleon (1793-1815). In peace time there appears to be little trend in deflated freight rates in the eighteenth and early nineteenth centuries. Around the middle of the nineteenth century frieghts begin a long decline. As a result frieghts in the early twentieth century are only about a third of the level that had prevailed prior to the mid nineteenth century.

II. Cotton Freights and North's Series

Douglass North's work on ocean shipping grew out of his estimation of the United States balance of payments. Before the Civil War, America was the greatest seafaring nation in the world and shipping earnings were an important component of international receipts. Estimation of these receipts required the collection of freight rates. Subsequently research was extended into the colonial period. The result is the only continuous series of ocean freight rates that extends from prior to the Industrial Revolution to the First World War.

North's research involved trades of North America and the West Indies. To a considerable extent the data reflect special characteristics of these relatively new trades. In the eighteenth century, piracy and its suppression in the Caribbean and settlement and the creation of distribution systems still influenced shipping in American waters. In the years following the Napoleonic war another new trade, this time cotton, dominated American shipping. 
since North's series was initially constructed to estimate shipping contributions to the American balance of payments, it is weighted in proportion to American exports. This assures that cotton export freight rates dominate the index in the early nineteenth century just as cotton exports dominated antebellum American exports. For example around 1850, total American exports valued about $\$ 135$ million, of this cotton contributed some $\mathbf{\$ 8 0}$ million. Cotton's domination extended to the volume of exports, which is more relevant for shipping, as is indicated in Table 2. Provisions, particularly pork products, exported initially by way of New orleans and later primarily from New York, made up a significant portion of the remaining American exports. This 1850 structure of trade is reasonably representative of antebellum trade in general. Some variation did, of course, occur. Most notably foodstuffs, particularly grain, were more important during the potato famine of the 1840 s and again during the period of high grain prices that accompanied the Crimean war in the middle of the 50 s. $^{9}$

[Table 2 about here]

Analysis of cotton shipments and their freight rates is subject to particular difficulties during most of the nineteenth century. On reflection, it is obvious that there are two ways to fill a ship. A ship is full either if it contains so much weight that more would make navigation unsafe or if its physical volume is filled. Some cargoes, 
coal and wheat, for example, approximately satisfy both constraints simultaneously; many, however, do not. The method of quoting freight rates usually accommodates this fact by expressing rates on heavy cargoes in terms of weight (usually tons weight) and light cargoes in terms of volume (a measurement ton, most commonly 40 cubic feet, although other volumes were widely used in various trades). cotton is unambiguously a light cargo but until late in the nineteenth century its freight was quoted in a weight unit - pence sterling per pound. Had the density at which cotton was packed not varied over time this would just be a curiosity; the historical investigator could proceed to analyze changes in shipping technology using the quoted freight rate. Unfortunately this was not the case.

In the early nineteenth century the trade in cotton grew rapidly to major commercial importance. In the course of that growth significant changes in organization occurred. The most important for our current concern was the development of improved means of packing cotton for shipment to reduce freight cost. In the early years of the American cotton trade, cotton was shipped in sacks, as smaller quantities had been shipped earlier from the West Indies and Brazil. The cotton was stuffed into the bags and compressed by men jumping on the cotton in the bag. This simple packing technology yielded a density of about five pounds per cubic foot. This density was increased as the bags were stuffed into the ships' holds. Shepherd and 
Walton's careful discussion of late eighteenth century shipping ${ }^{10}$ assumes a density of cotton in a ship of 12.5 lbs per cubic foot. As the trade developed screw presses were utilized on the plantations to create compressed bales of some 8 to 12 lbs. per cubic foot. These were also further compressed when "screwed" into a ship's hold. By the 1840 s the bales were being repressed (at the ships expense) by steam presses at the ports to a final density of between 20 and 25 lbs. per cubic foot for final shipment. 11

All of this is distressing imprecise. It is possible to do a little better. The British Customs Bills of Entry for various ports published ship arrivals and cargoes in the early nineteenth century. Fortunately some of those for Liverpool have been preserved. The earliest dates from 1820 and irregular years thereafter are available. 12 From these it is possible to calculate the number of bales of cotton a ship carried per registered ton at various dates. A complication remains, however, because the Bills of Entry report bales but the bale was not a homogeneous quantity. We do, however, have annual data for the average weight of an American bale exported to Britain. 13

[Table 3 about here]

Samples of ships and their cotton cargo have been drawn from the Liverpool Bills at various dates. These data are presented in Table 3. In 1820 the mean cotton ship in the sample had a tonnage of 313 registered tons and carried 
869 bales; 2.77 bales per ton. Since the average bale exported to Britain weighed 264 1bs, ships appear to have carried 732 lbs of cotton per register ton. In 1859 the average cotton ship was 1043 register tons and carried 3100 bales or 2.98 bales per ton. The average bale weighed 447 1bs. in 1859, so the average ship carried 1330 1bs. of cotton per register ton. It thus seems that the amount of shipping space occupied by a pound of cotton was cut nearly in half in the half century before the civil war. Even with no productivity increase in shipping this would have caused a reduction in cotton freights approximately proportional to the denser packing.

Although Doug North has been extremely helpful to me in my shipping research over the years, he has been unable to provide me with the complete details of his $U$. S. export freight rate series and $I$ have not yet collected sufficient data to reproduce it. I have obtained three series of cotton freight rates from American ports. From Charleston the series was provided to me a number of years ago by Professor North. That from New orleans, I recently extracted from the contemporary southern press. From 1820 on biweekly freight rates from New York, for cotton initially shipped coastwise and then exported to Europe, are available. 14 These series are presented in Figure 3 along with North's aggregate series.

[Figure 3 about here] 
The decline in the two southern cotton freight rates was about sixty percent between the early 1820 s and the late 1850s and seems to be largely a reflection of the increase in density of packing of cotton (see section $\mathrm{V}$, below). The New York series declines more rapidly suggesting some additional element in was present in the Northern port. Presumably this was an increasing quantity of westbound freight and passengers that paid an increasing portion of the round voyage costs. 15 North's aggregate series declines more rapidly than any of the individual series. After about 1830, however, his series declines at about the same rate as the New York cotton series. The rapid decline during the first two decades of the period may be an illusion created because North changed weights each decade to reflect the changing importance of various routes. During the second quarter of the century New York, with its lower rate of freight, gained predominance in American exports, particularly at the expense of southern ports as western exports were shipped east rather than south and as many southern exports were shipped north and transshipped for export in New York. 16

\section{Calculations of Productivity Change}

The British freight rate series presented in section II above obviously implies a different course of technological change over the nineteenth century than did North's 
data. British sources also yield somewhat different data for cost shares and input price trends than those presented by North.

Inspection of Figure 1 reveals a trend break around midcentury. Since short term fluctuations were so prevalent in shipping it is impossible to identify the exact date of the break. In addition the presence of marked fluctuations implies that trend rates of growth will be influenced by the choice of end points. In the calculations presented below end points have been chosen as the average over a complete fluctuation, from the first year of recovery to the following trought. Chosen years are 1818-1830, 18521858, 1908-13. These are imperfect in many ways. The 1850s includes the effect of the Crimean War but visual inspection suggests that the period is an adequate representation of trend. The immediate pre First World War cycle is incomplete.

Capital costs were considerably more important than North's calculations indicated. They are the share of income not paid out in the course of the voyage and attributable to the ship itself. They including depreciation, insurance and repair and are here allocated to the ship itself as they were in the accounting practices of shipping firms.17 In the calculations it is explicitly assumed that capital cost movements are adequately represented by ship prices. That is to say interest rates and depreciation are taken to have been substantially unchanged over the cen- 
tury. The shift from sailing ships to steam ships was a protracted process but as a general overview it is appropriate to consider the margin determining average freight rate as being occupied by sailing vessels until about midcentury and by steamers thereafter. The cost shares I have adopted for sailing ships and for steamers thereafter are presented in Table 4.

[Table 4 about here]

These cost shares have been combined with the estimate of input price change to calculate rates of total factor productivity change. These calculations are presented in Table 5. A very different path of productivity advance from that suggested by North's calculation emerges that confirms the impression of rapid advance after mid century suggested by Figure 3 .

Although well below North's estimate, substantial productivity advance occurs during the first half of the century while wooden sailing ships still dominated the shipping trades. 18 Advances in productivity during this period had several sources. Some improvement may have come from larger ships. Improvements in harbour facilities had considerable impact of shipping productivity by reducing the time spent in port. In a similar vein, steam power had its first impact on shipping during this period through the introduction of tug boats. Tugs helped to reduce port time and also reduced the problems and costs associated with manoeuvering larger vessels into river ports. 19 
As metal steam ships came to dominate ocean shipping productivity growth accellerated. Industrial technology also reduced shipping costs through the rapid fall in the price of metal steam ships. This fall in the price of ships lowered freight rates at close to half a percent annually (see section IV for more detail). Together productivity improvement in ship operation and lower ship prices lowered freight rates to just over forty percent of its initial value while general prices rose slightly.

[Table 5 about here]

IV. The Nature and Sources of Productivity Increase, 18731890: Two Case Studies

One of the most important aspects of North's path breaking JPE article was his attempt to go beyond the now familiar task of extimating total factor productivity by comparing the course of freight rates to the weighted sum of input prices. He attempted to associate the decline in costs with changing physical characteristics of the shipping trades he was investigating. A similar exercise is worth undertaking using the new data for the late nineteenth century. A comparison with North's original calculations is also instructive. North's calculations, however, were flawed in execution and have been reworked. 20 
Attribution of changing freight rates to input price and quantity changes utilizes the zero profit condition of Marshallian long run industry equilibrium. Total revenue equals total costs or

$$
P * Q=\Sigma w_{i} * z_{i}
$$

where $P$ is product price (freight rate in this case), $Q$ is the quantity of output, $w_{i}$ 's are factor prices and $z_{i}$ 's are factor input quantities. Arithmetic manipulation of the total differential of equation (1) yields the following relationship:

$$
\tilde{\mathrm{P}}=\Sigma \tilde{w}_{i} * s_{i}-\left(\tilde{Q}-\Sigma \tilde{z}_{i} * s_{i}\right)
$$

where expressions like $\tilde{p}$ indicate the rates of growth of the relevant variable and $s_{i}$ signifies the share of various input payment in total costs. The term $\left(\tilde{Q}-\Sigma \tilde{z}_{i} * s_{i}\right)$ in equation (2) is the familiar quantity calculation of technological change. 21

Examination of this expression provides insight into the factor savings in technological change. It seems appropriate to consider factor prices, including ship prices, to be exogenous in long run equilibrium since the shipping and shipbuilding industries, although not unimportant, were relatively minor influences in the labor, capital, engineering products and metal markets. of course, interpretation of the data must appreciate that factor utilization also responds to relative input prices.

A complicated combination of influences determined freight rates on any particular route, 22 therefore calcula- 
tions of influences leading to freight rate declines are most meaningful when carried out for specific, well identified trades. Consider, for example, the steam ship trade to Bombay and the sailing ship trade to the West coast of North America. These were two trades where the impact of the new technology was at its greatest. As a result freight rate declines and calculations of technological change considerably exceed the figures in Table 5. Table 6 presents data on prices and physical quantities of inputs for between the mid 1870 s and 1890 for these trades.

[Table 6 about here]

The voyage to Bombay through the suez Canal was the trade in which technological improvement in cargo steamers had its greatest impact. The opening of the suez Canal in 1869 created a unique opportunity for steamers in this trade and it emerged as by far the longest trade in which steamers competed successfully with sail for ordinary cargoes. Because a considerable portion of the carrying capacity of steamers was devoted to the carriage of fuel, the longer the voyage, and hence the greater the proportion of the carrying capacity devoted to fuel, the greater the impact of fuel saving technological improvement. The large impact of technological improvement here therefore reflects special aspects of this particular trade, nonetheless, it provides a useful illustration of the effect of new technology on freight rates. 
During the last half of the nineteenth century steamers gradually displaced sailing ships on longer and longer voyages. 23 The ton mile cost of operating steamers increased with voyage length because as the length of the voyage increased so did the proportion of the steamers capacity that had to be devoted to the carriage of fuel. coaling stations alleviated the problem only slightly during most of the period since most of the coal used in ocean navigation until very late in the century came from British coal fields. Thus any cost savings from not carrying coal and purchasing additional supplies at coaling stations such as Aden were effectively offset by the higher price of coal at these stations (there were considerable savings to be had by coaling at the north end of the suez canal on the return voyage; this is incorporated in the calculations). Consequently there was a distance margin at which cargo steamers and sailing ships competed on equal terms. On shorter voyages, cargo steamers dominated; on longer sailing ships. on the long voyages, cargo steamers could have been profitably employed only at higher freight rates than covered the full cost of sail. Since shippers of bulk cargoes were not prepared to pay such a premium, steamers were not generally employed. As steam technology improved relative to sail the margin moved to longer voyages.

At the end of the 1860s the margin between sail and steam lay on voyages about 3000 or 3500 miles in length. steamers were rapidly displacing sail on the North Atlantic 
and increasingly in the Black Sea (Odessa is about 3500 miles from the northern European ports). The trade to the American Gulf ports (New Orleans to northern Europe is just under 5000 miles), however, remained predominantly sail until the mid 1870s. Bombay which is about 11500 miles from northern European ports by way of the Cape of Good Hope and became about 6200 miles by way of the Suez Canal. Had the Canal been employed equally by sail and steam, the voyage to Bombay would have remained sail for about a decade after its opening. In fact, however, the canal was unusable by large sailing vessels because of the general lack of wind and the hazards to navigation in the Red sea. As a result steamers to Bombay using the shorter Canal route could charge considerably more than the rate per ton mile on the other routes in which steam competed with sailing ships and still meet or undercut the costs of sailing ships forced to use the longer cape route. The impact of improving steam technology was greatest on long voyages. In the Bombay trade this technological improvement resulted in freight declines while on other long voyages the initial impact of improved steam technology was not to lower freight rates but rather to allowed steamers to compete with sailing ships at the prevailing freight rate.

The second voyage in Table 6 is that to the west coast of North America. It was less anomalous than that to Bombay. It was the world's longest trade and continued to be dominated by sailing ships until the First World War. The 
improved sailing ship technology also had its greatest impact on such long voyages. The share of costs relating to relatively slowly falling port costs were smaller than in shorter trades and ships increased most in size in long voyages.

The central role of mechanical and metallurgical invention in the accelerated decline of freight rates and the acceleration of productivity change are clearly illustrated in Table 6 . The decline in coal consumption was the most obvious contribution of improved machinery to the increased productivity. Crews decreased because lower coal consumption meant fewer stokers to feed the boilers; improved rigs utilizing steel masts and rigging were more reliable; and newer metal ships were generally more reliable and easier to navigate. Even the reduction in ship weight associated with the use of steel rather than iron played a role.

Larger ships made an important contribution to declining freight rates. This is, of course, not strictly a result of improved mechanical technology. New technology did have some important effects since the large ships at mid century were close to the practical limit for wooden ships. That limit was removed by metal construction. At least as important in the increase in ships was improved organization of various trades and important improvements in port facilities and the handling of cargo. Port facilities were effectively the limiting constraint of ship size 
throughout the period. Optimal ship size was the result of balancing the savings of a larger ship at sea with the higher costs in port. If quantity of cargo handled per day had not grown rapidly, the economies of larger ships would have been rapidly dissipated by the capital costs of keeping larger ships in port for longer periods than smaller vessels.

The advance of technology caused not only an increase in productivity of shipping operation; it also caused the decline in ship and engine prices that made major contributions to falling frieghts. Ships and engines become cheaper because iron and steel become cheaper and because mechanical engineering and metal working improved.

It is useful to follow the impact of the new technology further even though the results must perforce be impressionistic rather than precise. The decline in the price of ships may be partitioned into effects of technological change in shipbuilding, the effect of falling iron prices, the course of wages, and the effect of the general fall in price. The years immediately following 1873 were years of deflation. Feinstein's GDP deflator fell at the rate of 1.1 percent per year between 1873 and 1890.24 Ship prices declined much more rapidly however at 3.7 percent per year. Technological change in shipbuilding generated a reduction of ship prices relative to the general price trend of about one percent per year. Iron prices fell very rapidly (just over 6.5 percent annually) from their boom heights. This 
rate of decline over and above general prices lowered ship prices nearly two percent per year faster than general price movements. This effect was only partially offset by the stability of nominal wages that raised ship prices by about a third of a percent relative to the general price level trend. 25

The fall in iron and steel prices in its turn was largely the result of technological change. The rapid decline in iron and steel prices was importantly influenced by the reversal of inflation and the elimination of high cyclical profits in iron and steel production that followed the business cycle peak in 1872 or 1873. The price of ship plates declined rapidly, however, even when allowance is made for these cyclical features. Between 1869/1870 (before the short term increases in iron prices during the inflationary boom of the early 1870s) and $1890 / 91$ prices of ship plates fell at nearly three percent per year. General deflation over that period was just under half a percent per year. Data on iron ore prices are uncertain but cleveland ironstone seems to have become cheaper at a rate of about one and a half a percent per year. This cheaper ore would have resulted in a fall in iron prices about a half a percent faster than the general price level. Wage rates, however, increased at nearly one percent per year and this would have offset more than half the effect of falling ore prices. There are no estimates of technological change in ship plates but Robert Allen's work implies an overall rate 
of technological change for the iron and steel industry of about half a per cent per year between 1850 s and the earliest years of the twentieth century ${ }^{26}$. Even if this change were concentrated in the 1870 s and $1880 \mathrm{~s}$, as much of it undoubtedly was, it would be insufficient to explain the decline in prices. Part of the answer may lie in the impact of such technological changes as the tall cleveland furnace and the Gilchrist-Thomas furnace that made possible the use of cheaper ores. In addition advance in ship plates was undoubtedly more rapid than in older sectors such as rails. My tentative conclusion is that Allen's work underestimates the impact of technological change in iron as far as shipbuilding is concerned. Most of the fall in iron prices over and above the general price movement should probably be attributed to technological change.

Following technological change backwards through the various stages of production produces a complete account for the impact of technological change; the data, of course, are such that any results must be regarded as very tentative. Consider the decline of Bombay freight rates for example. 1.1 of the 5.7 percent per year decline in the freight rate resulted from a general price decline. About three percent resulted from technological improvements in steam ships. The remaining one and a half percent decline may be attributed almost entirely to technological change in mechanical engineering in the construction of ships and in metallurgy in the production of metal plates. 
All of this is not to deny that improved organization contributed to productivity increase in shipping. The final "residual" in Table 6 resulted from more efficient utilization of vessels that reduced port time and improved load factors. Similarly the economies of larger ships were made possible largely by improved organization of trade that permitted the advantageous use of these vessels. But even here the march of invention played an important role. The improved organization of trade in the late nineteenth century depended on improved transportation and communications. It is hard to imagine that progress being duplicated in a world without steam transport on land and water. similarly the enormous change in the conditions of business communications that the telegraph and the marine cable made possible were essential for much of the organizational change of the era.

v. Comparison with American Antebellum Freight Declines

The decline in American export freight rates prior to the Civil War was of a fundamentally different character from those of the later part of the century. Analysis of the antebellum decline, based on North's data 27 is presented in Table 7 . Cotton freights from the southern cotton ports declined at an average rate of just over two percent per year. Input price changes account for little of this trend. In fact if more weight is given to ship prices, as I 
feel is probably appropriate, even this contribution is reduced. Some two thirds of the decline in freight resulted from the near doubling of the quantity of cotton carried in a register ton of shipping. The economies of larger ships accounted for the remainder of the decline. The ship sizes involved, however, were well within the technological capabilities of wooden ships although these wooden ships came increasingly to depend on low cost iron bracing of various types.

[Table 7 about here]

The greater decline in North's index and in the cotton freight from New York after the mid 1820s (the rate of freight rate decline from the southern ports is the same from the mid 20 s as from the 10s) will require more detailed investigation than has yet been done. North's suggestion that the increase in load factor was important is well taken. His allowance of a decline of about one percent per year to account for a shifting of round trip overhead increasingly onto westbound freight would account for the New York index's movements. Some care should be exercised here, however, since the economics of the distribution of overhead is somewhat more complex than North's calculation allowed. The effect of shifting overhead to westbound voyages was confined to the New York route. No allowance is appropriate for southern ports since no important shift in the balance of cargoes to southern ports occurred during the antebellum period. 
North's index still contains some unexplained decline even when load factors and the effect of increasingly efficient cotton packing are considered. The exercise here, however, is a considerable improvement on North's original calculation. The factors he analyzed accounted for only about half of the freight decline he identified. Unfortunately the original article left the impression that the decline in freights had been accounted for by the factors considered.

American export freight rates declined for special reasons. The tighter packing of cotton was the main cause. during the antebellum years. Cotton packing in turn was the result of the application of steam power to compressing cotton for shippment. This was a limited technology whose impact was confined to cotton. The great decline in freight rates occurred later as steam and metallurgical technology was applied to ships.

v. Conclusion

Douglass North's long accepted conclusion that the main decline in ocean freight rates was the result of improved economic organization and only slightly the result of industrial technology does not survive detailed reinvestigation. His conclusions were based on the experience of the relatively young American economy and are particular to it. Establishment of a mature commercial network were 
unusually important as eighteenth century American became integrated into the wider European economy. Early in the nineteenth century, American export freight rates fell rapidly as the export of cotton developed. Cotton was in great demand and so the cotton trade became more efficiently organized and in particular cotton was packed more efficiently for shipment.

The major improvements in shipping occurred after midcentury as the mechanical and metallurgical technology of the classical Industrial Revolution were applied to ocean transportation. A generation around mid century adopted metal hulls and steam propulsion in a significant technological departure from shipping technology of the preceding three centuries. The new vessels saved factor inputs and competiton in markets resulted in declining freight rates. 
Appendix A: North's Calculation Productivity Change and its Sources

North's calculations of the source of productivity change focused particularly on the effect of ship size (which involved a less than proportional increase in crew and capital), port time, and capacity utilization. In analyzing the pre Revolutionary period (using data from Walton's Ph.D. thesis) he also emphasized the decline in piracy in American waters, particularly in the West Indies, allowed a reduction in the manning and armament of ships. North undertook to identify the sources of falling freight rates by calculating the contributions of various physical changes. Unfortunately, this analysis, presented in his Table 3, is confused and seriously flawed. First and least seriously, the exposition in the text suggests that the sources of cost savings in the table equal the observed decline in freight rates. In fact, however, they do not. The calculations for the seventeenth and eighteenth centuries are presented in Table $A$ in a somewhat simpler manner than they were presented in North's article. North assumed that there were no changes in factor price or ship size during this period so freight declines should equal the weighted sum of the declines in factor inputs. This sum, however, amounts to only about half the decline in freight rates that North attributes to technological change. The other half of the decline in freight rates and improvement 
in technology is unaccounted for by the factors North considers.

[Appendix Table $A$ about here]

In the analysis of nineteenth century freight rate changes, the problems are more serious because North failed to maintain consistency within his calculation. The nineteenth century data in North's Table 3 analyzed the costs of a representative sized vessel at the beginning and end of the period. The adoption of larger vessels was an important source of productivity growth but unfortunate some calculations failed to reflect this increase in vessel size. These errors can be corrected fairly easily. This has been done in Table 7 . North's data have been used in this calculation with a minimum of adjustments to make the procedure internally consistent.

North calculated the rate of change in capacity and of costs for a typical ship between 1814 and 1860. This ship increased in size from 120 to 500 tons. Changing costs reflected changing factor prices and the economies of scale of larger ships. The rate of increase of size and capacity utilization indicated the increase in capacity. When the change in capacity is subtracted from the change in costs a calculated rate of change in unit costs, and equilibrium freight rates, emerges. Estimated technological change accounted for by these factors is then the difference between the calculated rate of change in unit costs and 
that part of the change in costs attributable to the change in factor prices.

The errors in North's calculation arose in the calculation of costs. The crew costs and ship costs are correctly estimated for the larger ship. "Other costs," however, which made up over half the total do not also reflect the larger ship. North had these costs change at the same rate as the Warren and Pearson price index (-1.46 percent per year). This is tantamount to assuming that a ship over four times as large used the same other inputs (port charges, repairs, insurance, victualing, etc.) as had the smaller ship of 1814 and that the prices of these inputs moved with the Warren and Pearson index. This is surely an error. I have made a rough correction on the following suppositions. Port dues and miscellaneous costs were proportional to the ship size times the Warren and Pearson index and thus increased at 2.65 percent annually. Repairs and insurance were proportional to the cost of the ship and so increased at 3.71 percent per year. Victualing costs were proportional to crew size multiplied by the Warren and Pearson index and increased at 0.30 percent per year. I have weighted these at 23 percent, 15 percent and 15 percent respectively of total cost. These rough assumptions yield the price and quantity figures in Table 7.

These revised calculations indicate that the capacity of a representative ship increased at a rate of 4.1 percent per year as a result of the larger ship and an improved 
utilization rate. Costs increased at a rate of 2.6 percent. This predicts that freight rates should have fallen at a rate of about 1.5 percent per year. This is far below the fall of North's freight index. The weighted factor price changes in the calculation fell at 0.21 percent per year (North's published costs series, which gives more weight to the Warren and Pearson index than I have, falls at 0.46 pre cent per year). The enumerated quantity changes identify technological change at a rate of 1.3 percent per year. These calculations, in fact, explain only a small fraction of North's freight rate decline. His use of them to discuss the nature of productivity increase is misleading. 


\section{Appendix B: Data Sources:}

1. Coal, Tyne to Iondon:

1741 - 1817: Lord Beveridge, et al., Prices and Wages in England from the Twelfth to the Nineteenth Century: Vol. 1 Price Tables: Mercantilist Era, (Frank Cass \& Co., Ltd., 1965 (Originally published 1939), pp. 264-271 and 294-295. Rates have been converted from shillings per chaldron to shillings per ton by multiplication by 0.85 .

1818-1835: From the testimony of James Bentley before the Select Committee on the Coal Trade, Parliamentary Papers, 1836, XI, p. 98 .

1836-1837: From the testimony of James Bentley before the Select Committee on the coal Trade (Port of London) Bill, Parliamentary Papers, 1837-8, XV, p. 79.

1838-1870: Extracted form freight quotations in the Newcastle courant, average of six quotes (first week of Jan., Mar., May, July, Sept., Nov. or nearest available date).

2. Timber, Baltic ports to London:

Various data, from various ports have been combined to create a series that represents the freight of st. Petersburg deals in pounds sterling per Petersburg hundred. The conversion of the quotes has been undertaken on the basis of the evidence on the ratio of rates on timber and deals from Riga, Memel and st. Petersburg presented to the select Committee on Manufactures, Commerce, and Shipping, Parliamentary Papers, 1833, VI, p. 457.

The data come from the following sources: 
S. C. on Manufacturing... PP, 1833, VI, P. 457.

S. C. on Timber Duties, PP, 1835, XIX, Qq. 5107-5109.

S. C. on Shipping, PP., 1844, VIII, Qq. 39, 1671, 1930.

Lord's Commission on the Navigation Laws, PP, 1847-8, $X X: I I, p \cdot 754$

Annual British Consular Reports from Baltic ports.

3. Timber, British North America to London:

Various series on timber and deals from Quebec and the Lower Ports (i.e. st. John and Miramichi) have been combined to create a series based on the st. John rate on deals in pounds sterling per standard, on the basis of average rates between 1817 and 1833 .

Sources are:

S. C. on Manufactures, Commerce, and Shipping, P.P., 1836, VI, pp. $342,368-371,444$.

S. C. on Shipping, P.P., 1844, VIII, Qq. 1671, 1926.

Lord's Commission on the Navigation Laws, PP, 1847-8, $X X: I I, p .754$

4. Cotton, U. S. Ports to Liverpool:

Charleston: Data provided by Douglass North. Original source New York Shipping and Commercial List.

New Orleans: Prior to 1836 the data has been extracted from the Charleston Courier usually quoting New Orleans Prices Current (whose dates have been used). There after the information has been obtained from the New orleans commercial Bulletin. The series has been constructed from quotes for the first weeks of October, December, February and 
April (or nearest available dates). Prior to the late 1830 s quotes were usually not available for every month. In the late antebellum period the data has been taken from the Commercial Bulletin's annual report of the cotton market published in the first issue in september from 1855.

New York: Quotations have been taken from the first week in November, January, March and May from E.J.Donnell, Chronological and statistical History of Cotton, (New York: the author, 1872. Reprinted wilmington, Del.: Scholarly Resources, Inc, 1973).

5. Input Prices for Table 5

a. Ship prices:

1818/30: Various testimony before the S.C. on Foreign Trade, 1821, PP and S.C. on Manufactures, Commerce and Shipping, 1833 PP VI suggests that top class (12AI) vessels fitted complete for an Eastern voyage cost about $f 24$ if built in London and $\mathbf{f l 9}$ per ton if built elsewhere. A more modest vessel suitable for the timber and coal trades cost between $£ 13$ and $£ 15$ in the northern ports.

1852/58: A ship of first quality with complete outfit (12-13A1) cost £14-18 per ton as did a metal sailing ship. A northern built vessel or a colonial vessel (9-10A1) cost £10-12. Steamers cost $£ 22.2$ per gross register ton. (See C. K. Harley, "Shipbuilding and shipping in the late nineteenth century." Unpublished Ph. D. dissertation, Harvard University, 1972, pp. 111-136 and 255-271 for a discussion of available data on ship prices.) 
1908/13: Steamer price $\$ 11.8$ per gross ton. All the steamer prices are an average of quotes from the records of Alexander Stephens and Connell in Glasgow and Grey of Hartlepool (Robert Craig, "William Gray \& Co.: a West Hartlepool shipbuilding enterprise" in P. H. Cotterell and D. Aldcroft, eds., shipping, Trade and Commerce: Essays in Memory of Ralph Davis (Leicester: Leicester University Press, 1981), p. 185).

\section{b. Wages:}

1818/30: Tyne to Baltic, monthly, s.c. on Manufactures..., 1833 PP VI, p. 445 .

1852/58: Tyne to Baltic, monthly, "Wages of seamen (British Ships)" 1867 Pp LXIV.

1852/58 to 1918/11: Average of wages to Mediterranean ports from Liverpool, London, and Tyne Ports, reported in the annual "Progress of Merchant Shipping". These have been extrapolated to 1913 on the basis of Bowley's series in Mitchell, Historical Statistics..., p. 344 .

c. General prices:

An approximation of a GNP deflator has been chosen instead of a wholesale index. The majority of the costs in this category involve loading and unloading, a highly labor intensive activity. other items in this residual category include seamen's victualling, and a certain amount of routine items in a ships equipment. This is also the deflator used in Figure 1. 
1741-1790: Gilboy/Schumpeter index in Mitchell, Historical Statistics, p. 469.

1790-1830: Gayer, Rostow and Schwartz overall series in Mitchell, Historical Statistics, p. 470.

1830-1870: The implicit deflator calculated from Phyllis Deane, "New Estimates of Gross National Product for the $U$. K. 1830-1914," Review of Income and Wealth, 14 (June 1968), pp. 104-107.

1870-1913: Charles Feinstein, National Income, Expenditure and output of the United Kingdom, 1855-1965 (Cambridge: Cambridge University Press, 1972), p. T132.

\section{d. Coal:}

The average export price of British coal, Mitchell, Historical Statistics, p. 483. 1. See for example, D. N. Mccloskey, "The industrial revolution 1780-1860: a survey." In Roderick Floud and D. N. Mccloskey, eds., The Economic History of Bxitain since 1700: 1. 1700-1860. (Cambridge: Cambridge University Press, 1981), pp. 114 and 125. McCloskey uses North's results to indicate that ocean and coastal shipping had rates of productivity improvement that were among the most rapid in the economy.

2. The most important work in this reassessment is that of N. F. R. Crafts summarized in his

3. See Douglass North, "Ocean Freight Rates and Economic Development 1750-1913." Journal of Economic History XVIII (Dec. 1958); Douglass North, "The role of transportation in the economic development of North America." Les Grandes Voies Maritimes Dans Le Monde, XV-XIX Siecles. (Paris: SEVPEN, 1965), pp. 209-246 and James F. Shepherd and Gary M. Walton, shipping, maritime trade and the economic development of colonial North America (Cambridge: Cambridge University Press, 1972), Ch. 5, Appendices III and IV. North's most important article in this series is "Sources of Productivity Change in Ocean Shipping, 1600-1850," Journal of Political Economy, 76 (Sept/Oct., 1968), pp. 953-970. 
4. North's series is available on an annual basis only after 1815. I have extended the series back into the eighteenth century. I have followed Mccloskey's assumption ("Industrial revolution" p. 125), that the rate of increase in productivity implied between 1784 and 1815 must have been about 1 percent per year. Between 1741 and 1784, I have not used the rate of 0.45 percent per year in North, "Productivity" but followed Shepherd and Walton, (Shipping, p.72) in assigning the growth in productivity to the century after 1680 at a rate of 0.8 percent per year. I have allowed for general price changes using the Gilboy/Schumpeter index (B. R. Mitchell, with Phyllis Deane, Abstract of British Historical statistics (Cambridge: Cambridge University Press, 1962), pp. 468-9) and considering the 1784 price level to have been .7 relative to $1817-21$ and the 1740 price level to have been .56. North's immediate post war freights are very volatile so the graph plots the average of the years 1815 to 1820 .

5. For a detailed discussion of the freight rate date used to construct these new estimates see the data appendix.

6. It is obvious that these are not perfect quotations. An interesting literature on similar matters has developed recently in the Economic History Review. See simon ville, "Total factor productivity in the English shipping industry: the north-east coal trade, 1750-1850". 2nd. ser. XXXIX (1986), pp. 355-70; William J. Hausman, "The English coastal coal trade, 1691-1910: how rapid was productivity growth?" 2nd.ser XL (1987), pp. 588-596; and simon Ville, "Defending productivity growth in the English coal trade during the eighteenth and nineteenth centuries." 2 nd. ser. XL (1987), pp. 597-602. To some extent this literature is confused by its failure to recognize the shortcomings of North's series.

7. L. Isserlis, "Tramp Shipping Cargoes, and Freights", Journal of the Royal statistical society, 1938. The series is reproduced in Mitchell, Historical Statistics, p. 224.

8. Parliamentary Papers, 1844, VIII, p. 218.

9. U. S. Bureau of the Census, Historical Statistics of the United States, (Washington: GPO, 1960), p. 547 .

10. Shepherd and Walton, Shipping..., p.238.

11. For a discussion of the packing of cotton see Harry Bates Brown, Cotton (New York: McGraw Hill, 1927), pp.340350 and Harry Hammond, "The Handling and Uses of cotton," in U.S.D.A.', The cotton Plant, office of Experiment stations Bulletin, no. 33, 1896, pp. 360-365. 
12. The Bills of Entry are currently in the Customs House, London. Not all years survived. The years chosen in the 1820 s and 1830 s are the earliest available. Most of the increased density of packing seems to have been accomplished by the late 1830s. Consequently only 1859 was sampled for the late antebellum period.

13. Matthew B. Hammond, The cotton Industry, (New York: MacMillan, 1897), Appendix I provides information for U.S. cotton exports in both pounds and bales. The figure for bales exported in 1827 is reported as 446 thousand. This is a typographical error (which is carried over into Table $3 \mathrm{~A}$ in Stuart $w$. Bruchey, cotton and the Growth of the American Economy 1790-1860, (New York: Harcourt, Brace \& World, 1967). The correct figure is 646 .

14. See data appendix for details. I have recently discovered published series on cotton freights from New York and New Orleans in North's United States that I had somehow overlooked during many years of research on this topic. Fortunately although the series are not identical to mine they are very similar. The separately compiled series mutually reinforced their credibility.

15. Analysis of the effect of increasing westbound traffic on the Atlantic is more complicated than a simple counting. Detailed analysis beyond the scope of this paper. The basis features of the analysis are considered in C. Knick Harley, "Aspects fo the Economics of Shipping, 1850-1913," in Lewis R. Fischer and Gerald E. Panting, eds., Change and Adaptation in Maritime History: The North Atlantic Fleets in the Nineteenth Century (st. John's: Memorial University of Newfoundland, 1985) pp. 169-186, and Harley, "Coal Exports and British Shipping, 1850-1913", forthcoming.

16. For the transshipment of southern exports see Robert G. Albion, Square Riggers on Schedule: The New York Sailing Packets to England, France and the cotton Ports. (Princeton: Princeton University Press, 1938).

17. Among the most accessible of these type of accounts are those of the Ben Line at the University of Edinburgh, those of William Bates and Sons at the National Maritime Museum at Greenwich and those in the Donaldson Records in the Strathclyde Regional Archives.

18. This rate of productivity advance is consistent with the results arrived at in ville, "Total factor productivity.." using a quite different approach.

19. An excellent discussion of the various factors contributing to productivity advance during this period is to be found in ville, "Total Factor Productivity...". 
20. For details see Appendix A.

21. The formal basis of this calculation corresponds to those underlying the more familiar solow calculation of Hicks' neutral technological change which is the term on in parentheses on the right hand side of equation (2). The zero profit industry equilibrium condition in that case is used, often implicitly, to justify the share utilization of income shares in place of the marginal products that emerge from the differential of the production function.

22. See the discussion referred to in note 14 above.

23. For a detailed discussion of these issues see $C . K$. Harley, "The shift from sailing ships to steam ships, 1850$1890^{\prime \prime}$ in D. N. McCloskey, ed. Essays on a Mature Economy: Britain after 1840 (London: Methuen \& Co. Ltd., 1972), pp. 215-234.

24. Charles M. Feinstein, National Income, Expenditure and output of the United Kingdom, 1855-1965. (Cambridge: Cambridge University Press, 1972) p. T132.

25. Details of these calculations are available in $c . K$. Harley, "Shipbuilding and Shipping in the Late Nineteenth Century," Unpublished Doctoral Dissertation, Harvard University, 1972, pp. 302-312.

26. See Robert Allen, "International competition in Iron and Steel, 1850-1913," Journal of Economic History, XXXIX (Dec. 1979), pp. 911-938. Some additional information has been made available to me privately by Professor Allen. He is not, of course, responsible for the uses it has been put to.

27. There were several additional errors in North's calculations in addition to the failure to recognize the special character of cotton cargoes. These are discussed in the appendix. 
Table 1

Employment of Shipping in British Trade ('000 Tons)

Total British shipping

1824

$\underline{1844}$

in Foreign and Colonial trade: $1056.5 \quad 1666.3$ of which:

British North America

Baltic

Other Europe

East Indies

India

Far East and Australasia

United States

$\begin{array}{rr}1056.5 & 1666.3 \\ 256.7 & 504.8 \\ 167.8 & 182.0 \\ 110.3 & 211.6 \\ 170.3 & 149.5 \\ 60.8 & 258.8 \\ 53.1 & 102.2 \\ 22.5 & 60.9 \\ & \\ \text { n.a. } & 1359.6 \\ 307.8 & 464.1 \\ 193.9 & 236.0 \\ 76.7 & 147.1 \\ 36.3 & 72.6\end{array}$

Coastal shipping

Foreign Shipping in British Trade:

of which from:

Baltic

United states

Other Europe

Source: G. F. Young's testimony, "The select committee on the state and condition of the Commercial Marine", p.218. Parliamentary Papers 1844 VIII. 
Table 2

U.S. Exports, around 1850

\begin{tabular}{|c|c|c|c|}
\hline & $\begin{array}{l}\text { Value } \\
\text { (s mn.) }\end{array}$ & $\begin{array}{l}\text { Weight } \\
\text { (mn. Ibs) }\end{array}$ & $\begin{array}{c}\text { Volume } \\
\text { (th. tons) }\end{array}$ \\
\hline $\begin{array}{l}\text { Total } \\
\text { Cotton } \\
\text { Tobacco } \\
\text { Wheat and flour }\end{array}$ & $\begin{array}{r}135 \\
80 \\
8 \\
8\end{array}$ & $\begin{array}{r}1,000 \\
110 \\
320\end{array}$ & $\begin{array}{r}1,250 \\
110 \\
160\end{array}$ \\
\hline
\end{tabular}

Source: Historical statistics. Volume was calculated from the freight factors in Robert White stevens, on the stowage of Ships and their Cargoes, (1858).

Table 3

Cotton Carried per Registered Ton, 1820-1859

$\begin{array}{rrrrrrr}\text { Date } & \begin{array}{c}\text { Sample } \\ \text { Size }\end{array} & \begin{array}{c}\text { Average } \\ \text { tonnage }\end{array} & \begin{array}{c}\text { Average } \\ \text { bales } \\ \text { carried }\end{array} & \begin{array}{c}\text { Bales } \\ \text { per } \\ \text { ton }\end{array} & \begin{array}{l}\text { Ibs. } \\ \text { per } \\ \text { bale }\end{array} & \begin{array}{r}\text { Ibs. } \\ \text { per } \\ \text { ton }\end{array} \\ 1820 & 39 & 311 & 865 & 2.8 & 264 & 731 \\ 1827 & 39 & 340 & 1026 & 3.0 & 331 & 1003 \\ 1834 & 52 & 370 & 1225 & 3.3 & 363 & 1197 \\ 1837 & 46 & 428 & 1390 & 3.2 & 379 & 1228 \\ 1859 & 79 & 1041 & 3100 & 3.0 & 447 & 1332\end{array}$

Source: Ship data from the U.K. Customs Bills of Entry forliverpool. The weight per bale is calculated from the data on the number of bales and the number of pounds exported from the United states to Britain in Hammond, The Cotton Industry, Appendix I. The number of bales exported to Britain in 1827 is reported as 446 thousand. This is a typographical error. The correct figure is 646 . 
Table 4

Cost Shares, Sail and steam Ships, Nineteenth Century

Ship prices:

Sail

Steam

Wages:

Misc.:

0.40

0.27

0.33

0.40

Coal:

na

0.10

0.30

0.20

Sources: These are based on cost from a large number of nineteenth century manuscript voyage accounts. The sail shares are heavily influenced by the Henley accounts at theNational Maritime Museum in Greenwich. The steam accounts are heavily based on the Ben Line accounts at the University of Edinburgh Library.

Table 5

Freight and cost Changes and Productivity Growth

\begin{tabular}{lcc} 
& $\begin{array}{c}1811 / 30-1852 / 58 \\
(\text { Sail) }\end{array}$ & $\begin{array}{c}1852 / 58-1908 / 13 \\
\text { (Steam) }\end{array}$ \\
\cline { 2 - 3 } Freight: & $-0.88 \%$ per year & $-1.51 \%$ per year \\
Ship prices: & $-0.89 \%$ & $-1.14 \%$ \\
Wages & $+1.16 \%$ & $+0.55 \%$ \\
Misc. prices: & $-0.61 \%$ & $+0.13 \%$ \\
Coal prices: & & $+0.54 \%$ \\
Productivity & & \\
$\quad$ change: & $+0.63 \%$ per year & $+1.26 \%$ per year
\end{tabular}

Sources: see the data appendix. 


$$
\begin{gathered}
\text { Table } 6 \\
\text { Explanation of Declining Freights, } 1870 \text { s-1890 }
\end{gathered}
$$

Prices and Physical Relationships

$$
\begin{array}{cc}
\text { Bombay } & \text { California } \\
\text { (steam) } & \text { (sail) }
\end{array}
$$

\begin{tabular}{|c|c|c|c|c|c|}
\hline Freights & 46 & 16 & 70.7 & 55.1 & 33.2 \\
\hline $\begin{array}{l}\text { Prices: } \\
\text { Ship Prices: } \\
\text { Wages: } \\
\text { Port Charges: } \\
\text { Coal: }\end{array}$ & $\begin{array}{l}53,000 \\
134 \\
\text { Fal1 } 2 \% \\
21.0\end{array}$ & $\begin{array}{c}28,000 \\
156 \\
\text { per year } \\
13.5\end{array}$ & $\begin{array}{r}19.5 \\
127 \\
.67 \\
--\end{array}$ & $\begin{array}{r}15.6 \\
126 \\
.67 \\
--\end{array}$ & $\begin{array}{r}10.9 \\
126 \\
.59 \\
--\end{array}$ \\
\hline $\begin{array}{l}\text { Physical Changes: } \\
\text { Crew size: } \\
\text { Ship weight: } \\
\text { coal consumption: }\end{array}$ & $\begin{array}{l}3.9 \\
100 \\
2.1\end{array}$ & $\begin{array}{r}1.9 \\
90 \\
1.5\end{array}$ & $\begin{array}{l}2.5 \\
100\end{array}$ & $\begin{array}{l}2.5 \\
100\end{array}$ & $\begin{array}{r}2.0 \\
93\end{array}$ \\
\hline $\begin{array}{l}\text { Economies of larger } \\
\text { Ship size: } \\
\text { Crew savings: } \\
\text { Ship cost: } \\
\text { Coal: }\end{array}$ & 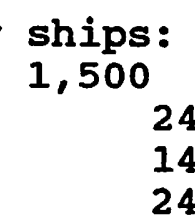 & $\begin{array}{l}3,000 \\
\frac{\%}{\%} \\
\frac{\%}{8}\end{array}$ & 1,000 & $\begin{array}{r}1,000 \\
30 \% \\
6 \%\end{array}$ & 2,000 \\
\hline
\end{tabular}

$1873 / 4 \quad 1890 / 1 \quad 1873 / 4 \quad 1874 / 6 \quad 1890 / 1$

Freight Decline and Contributions:

$\begin{array}{lcrr}\text { Freight } & 1873 / 4-1890 / 1 & 1875-1890 & (1873-90) \\ \text { Contribution of: } & -5.7 \% & -3.8 \% & (-4.3 \%) \\ \text { Ship prices: } & -1.9 \% & -1.1 \% & (-1.2 \%) \\ \text { Other input prices: } & -0.7 \% & -0.5 \% & (-0.7 \%) \\ \text { ["Total factor productivity" } & -3.1 \% & -2.2 \% & (-2.4 \%) \\ & & & \\ \text { Coal consumption: } & -1.1 \% & & \\ \text { Ship size: } & -0.7 \% & -0.9 \% & (-0.9 \%) \\ \text { Weight of ship: } & -0.4 \% & -0.4 \% & (-0.4 \%) \\ \text { Crew size: } & -0.4 \% & -0.4 \% & (-0.4 \%) \\ \text { "Residual": } & -0.5 \% & -0.5 \% & (-0.7 \%)\end{array}$

Source: C. K. Harley, "Shipbuilding and shipping in the late nineteenth century," Unpublished Ph. D. dissertation, Harvard University, 1972, pp. 308-312. 
Table 7

Freight Rates, Costs and Technological Change American Antebellum Cotton

Freight rate decline (1814/6 to $1858 / 60)$ : North's series: $4.25 \%$

Southern ports:

New York $(1823 / 5-1858 / 60): 3.1$ \%

Input prices: changes shares contribution

$\begin{array}{llcl}\text { wages } & +0.48 & 0.30 & +0.15 \\ \text { ship } & +0.60 & 0.17 & +0.10 \\ \text { other } & -0.87 & 0.53 & -0.46 \\ \text { ted average of input price changes: } & -0.23\end{array}$

Weighted average of input price changes: -0.23

Productivity advance:

(Freight rate decline less input price decline)

North's series:

$4.0 \%$ annually

Southern ports:

$1.9 \%$ annually

New York:

$2.9 \%$ annually

Effect of ship size:

Smaller crew per ton

rate effect on freight

other inputs per ton

$1.7 \%$

$0.8 \%$

$-0.5$

$-0.2$

Effect of increasing load factor:

$-1.0$

Effect of increased cotton density:

$-1.5$

Freight decline accounted for:

Without increased load factor: $\quad 2.4 \%$ annually

with increased load factor:

$3.4 \%$

Source: North [1968], Table 3 and Appendix and Appendix A below. 
Figure 1

Freight Rates, Deflated, 1741-1913

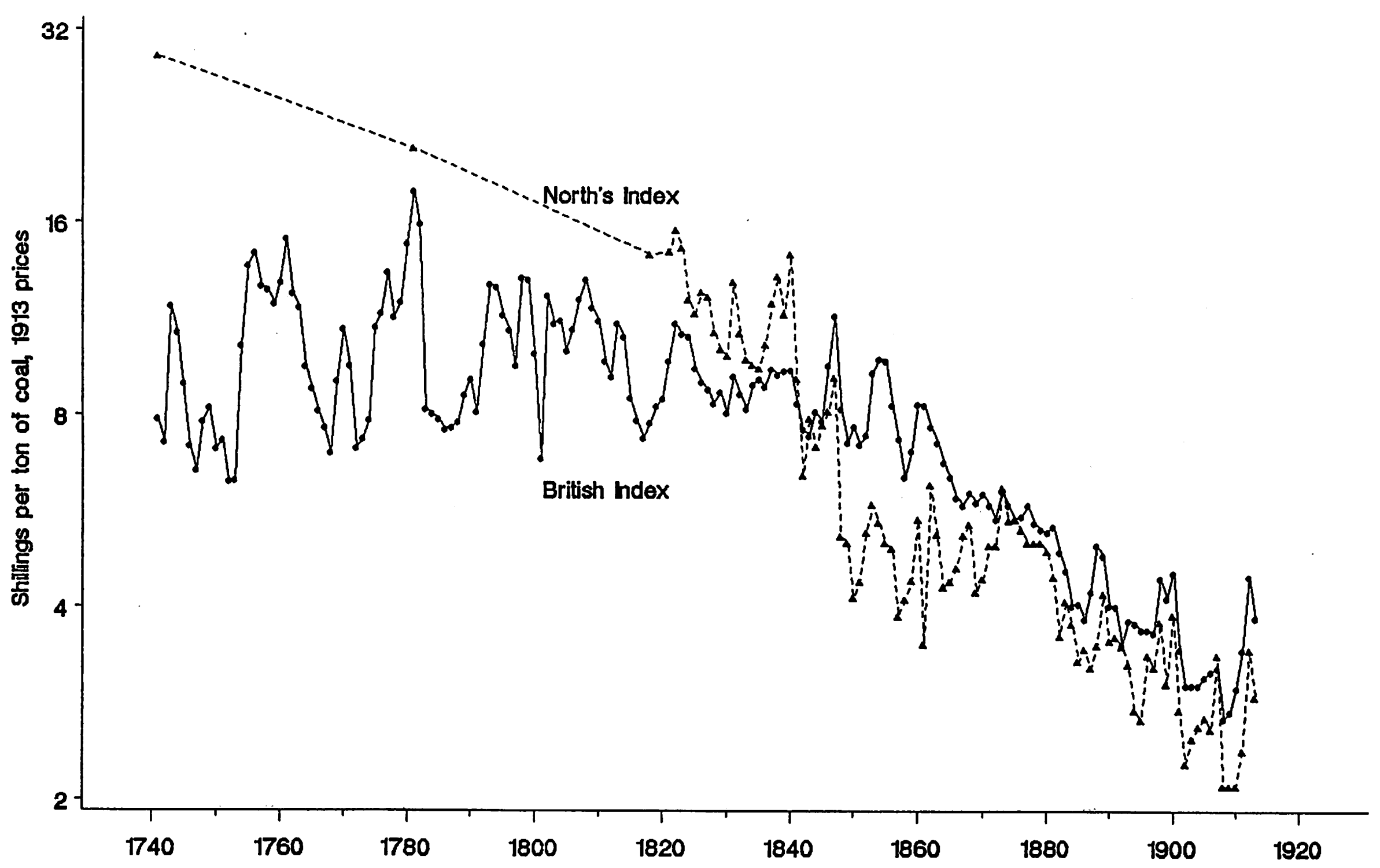


Figure 2

British Freight Rates, 1741-1872

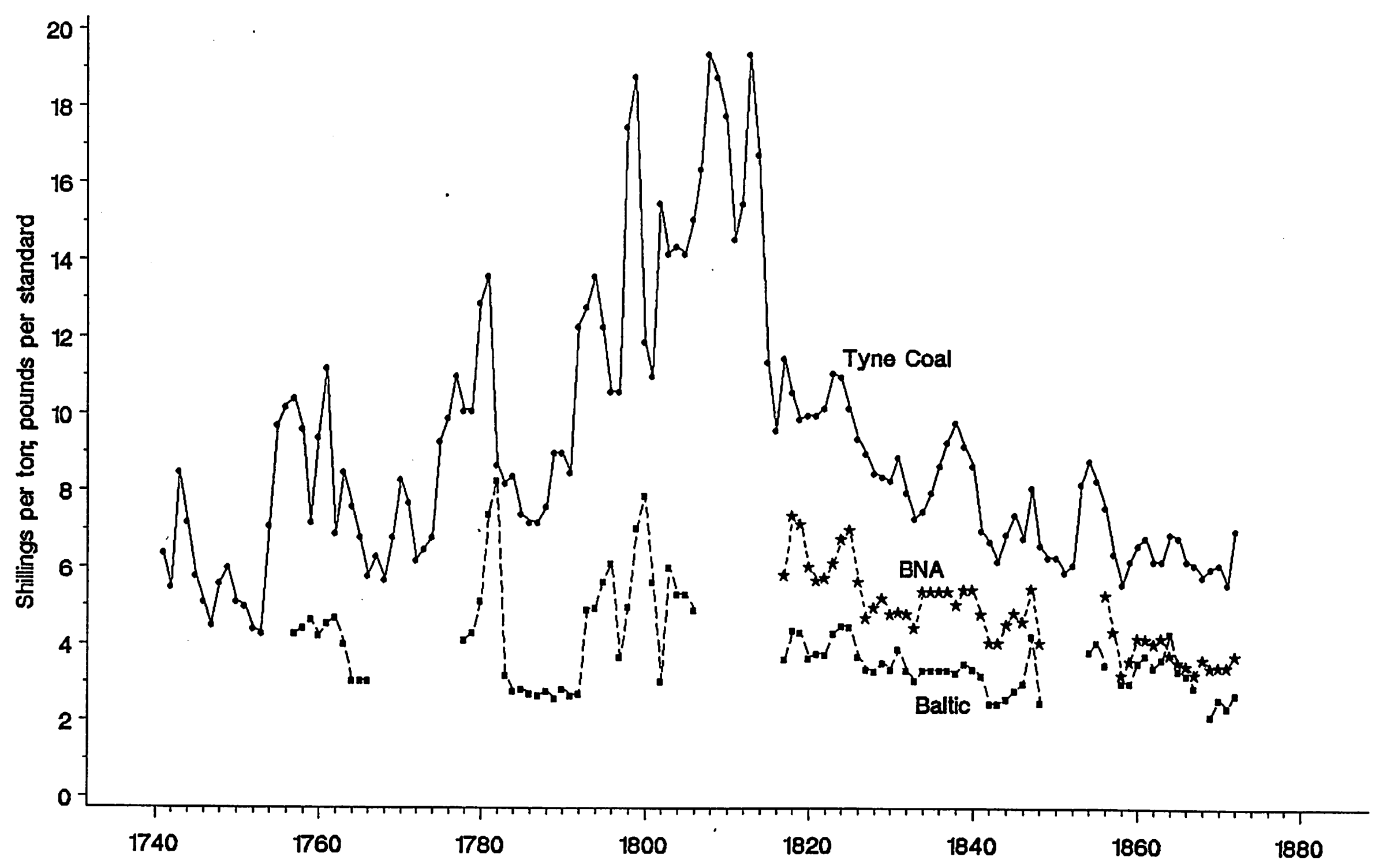

Source: See text. 
Figure 3

North's Index and Cotton Freights, 1820-1860

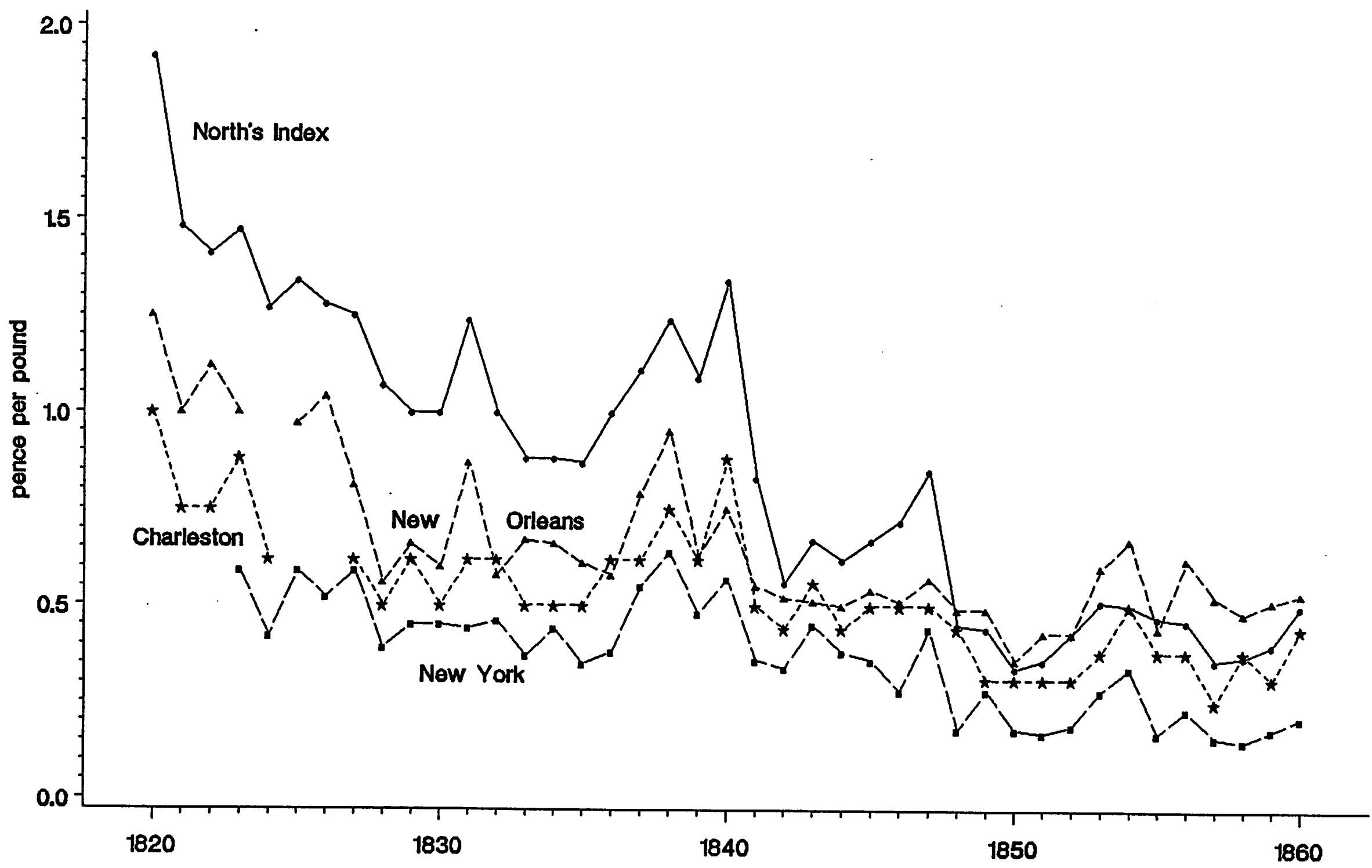




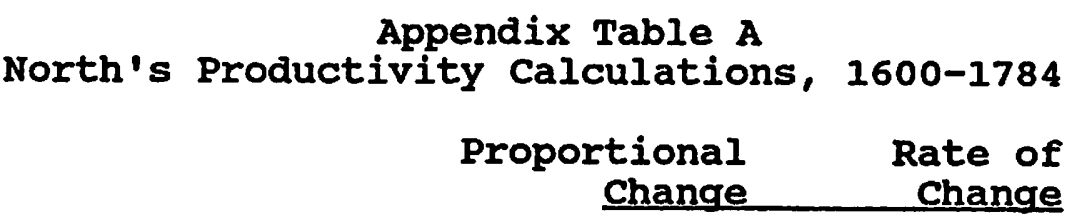

Crew

At sea

In port

Capital

At sea

In port

Other inputs

At sea

In port

0.50

0.75

$-0.37$

$-0.15$

$1.00 \quad 0.00$

0.50

$-0.37$

0.70

$-0.20$

0.72

$-0.18$

Predicted freight change

$-0.22$

Actual freight change

$-0.45$

Unaccounted technological change

$0.23 \%$ per year

Source: North [1968], Table 3 . 


\section{Appendix Table B \\ Freight Rate Data, 1741-1913}

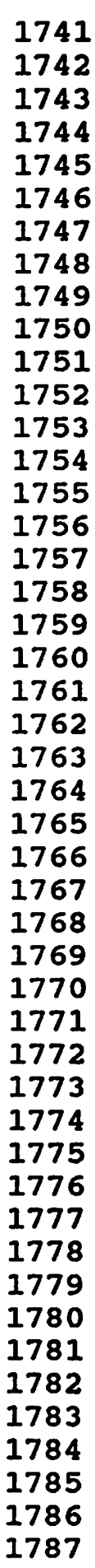

\begin{tabular}{|c|c|c|c|c|}
\hline Coal & Petersburg & BNA & Odessa & $\begin{array}{l}\text { New Yor } \\
\text { grain }\end{array}$ \\
\hline 6.40 & • & - & - & - \\
\hline 5.50 & - & - & - & - \\
\hline 8.50 & - & - & - & - \\
\hline 7.20 & - & • & - & - \\
\hline 5.80 & - & - & - & - \\
\hline 5.10 & - & - & - & - \\
\hline 4.50 & - & - & - & - \\
\hline 5.60 & - & - & - & - \\
\hline 6.00 & - & - & • & - \\
\hline 5.10 & $\bullet$ & - & - & - \\
\hline 5.00 & - & - & - & - \\
\hline 4.40 & - & - & - & - \\
\hline 4.30 & - & - & - & - \\
\hline 7.10 & - & - & - & - \\
\hline 9.70 & - & - & - & - \\
\hline 10.20 & $\therefore$ & $\bullet$ & - & - \\
\hline $\begin{array}{r}10.40 \\
9.60\end{array}$ & $\begin{array}{l}4.29 \\
4.43\end{array}$ & • & $\bullet$ & - \\
\hline $\begin{array}{l}9.60 \\
7.20\end{array}$ & $\begin{array}{l}4.43 \\
4.64\end{array}$ & $\dot{.}$ & $\stackrel{\bullet}{\bullet}$ & $\bullet$ \\
\hline $\begin{array}{l}7.20 \\
9.40\end{array}$ & $\begin{array}{l}4.64 \\
4.24\end{array}$ & $\dot{\bullet}$ & $\dot{\bullet}$ & $\dot{.}$ \\
\hline 11.20 & 4.55 & - & - & • \\
\hline 6.90 & 4.69 & - & - & - \\
\hline 8.50 & 4.02 & - & - & - \\
\hline 7.60 & 3.05 & - & - & - \\
\hline 6.80 & 3.05 & - & - & - \\
\hline 5.80 & 3.05 & - & - & - \\
\hline 6.30 & • & - & - & - \\
\hline 5.70 & - & - & - & - \\
\hline 6.80 & - & - & - & - \\
\hline 8.30 & - & - & - & - \\
\hline 7.70 & - & • & - & - \\
\hline 6.20 & - & - & - & - \\
\hline 6.50 & - & - & - & - \\
\hline 6.80 & - & - & - & $\bullet$ \\
\hline 9.30 & - & - & $\bullet$ & - \\
\hline 9.90 & - & - & - & $\bullet$ \\
\hline 11.00 & $\therefore$ & - & $\bullet$ & • \\
\hline 10.10 & 4.12 & - & - & • \\
\hline $10 \cdot 10$ & 4.31 & - & - & $\cdot$ \\
\hline 12.90 & 5.13 & - & - & - \\
\hline $\begin{array}{r}13.60 \\
8.70\end{array}$ & $\begin{array}{l}7.41 \\
8.27\end{array}$ & • & - & - \\
\hline $\begin{array}{l}8.70 \\
8.20\end{array}$ & $\begin{array}{l}8.27 \\
3.21\end{array}$ & $\bullet$ & - & $\dot{0}$ \\
\hline $\begin{array}{l}8.20 \\
8.40\end{array}$ & $\begin{array}{l}3.21 \\
2.79\end{array}$ & $\dot{\bullet}$ & $\bullet$ & : \\
\hline $\begin{array}{l}8.40 \\
7.40\end{array}$ & 2.83 & • & $\dot{\bullet}$ & : \\
\hline 7.20 & 2.72 & - & $\dot{0}$ & $\dot{0}$ \\
\hline 7.20 & 2.67 & . & - & . \\
\hline
\end{tabular}

British

Series

6.40

5.50

8.50

7.20

5.80

5.10

4.50

5.60

6.00

5.10

5.00

4.40

4.30

7.10

9.70

10.20

10.39

10.16

9.21

9.83

11.10

9.12

9.11

7.49

7.09

6.59

6.30

5.70

6.80

8.30

7.70

6.20

6.50

6.80

9.30

9.90

11.00

10.03

10.26

12.66

15.76

14.35

7.98

7.58

7.12

6.89

6.83 
Coal Petersburg BNA Odessa New York British

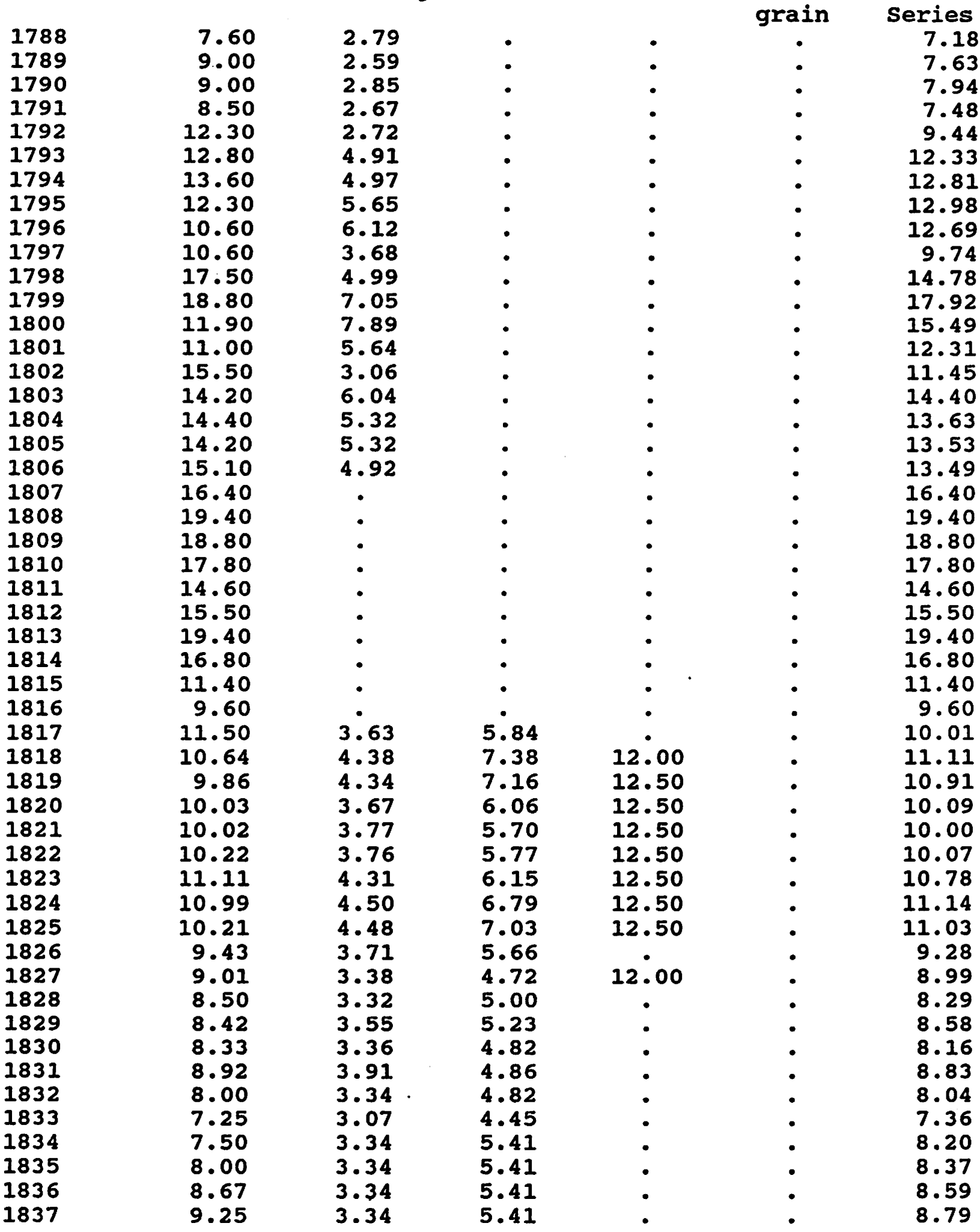


coal Petersburg BNA

\section{8 \\ 1839 \\ 1840 \\ 1841 \\ 1842 \\ 1843 \\ 1844 \\ 1845 \\ 1846 \\ 1847 \\ 1848 \\ 1849 \\ 1850 \\ 1851 \\ 1852 \\ 1853 \\ 1854 \\ 1855 \\ 1856 \\ 1857 \\ 1858 \\ 1859 \\ 1860 \\ 1861 \\ 1862 \\ 1863 \\ 1864 \\ 1865 \\ 1866 \\ 1867 \\ 1868 \\ 1869 \\ 1870 \\ 1871 \\ 1872}

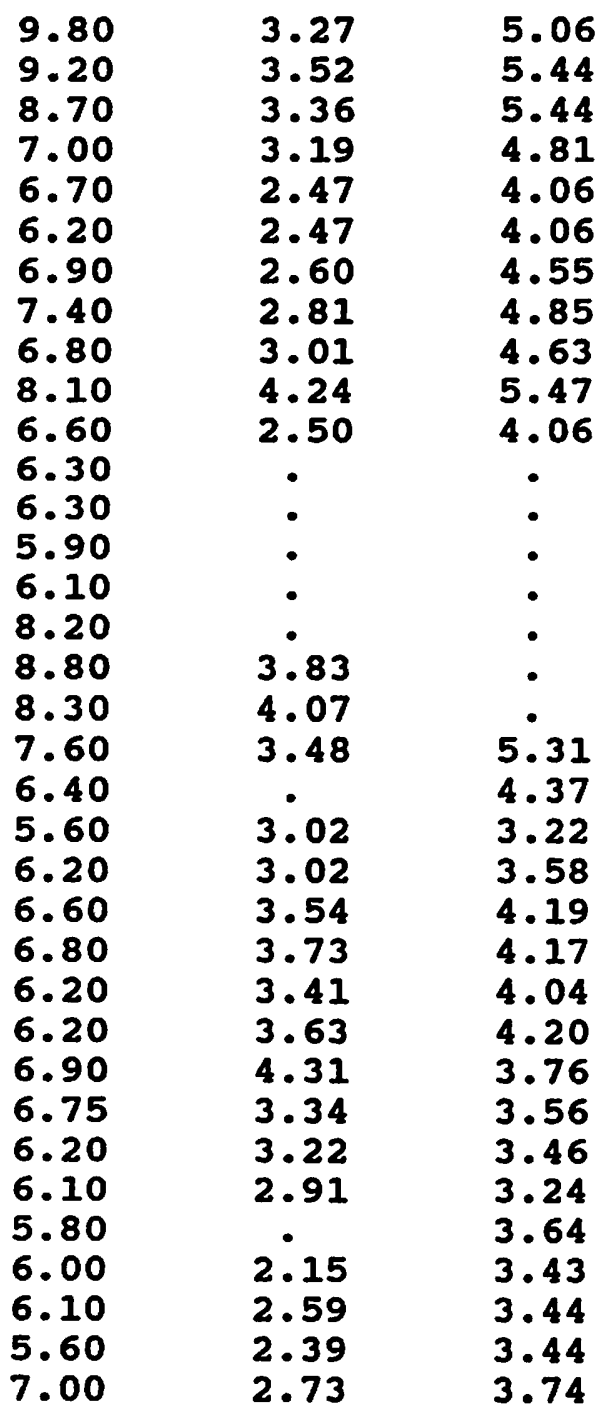

\section{Odessa New York grain}

10

8.50

7.70

7.00

8.10

5.50

13.50

16.60

10.00

7.90

7.20

7.70

10.00

17.30

.

7.46

7.50

6.78

6.72

7.57

8.02

7.47

6.65

7.05

6.84

7.48

7.03

6.42

6.13

6.30

6.13

5.79

6.36

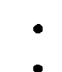

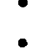

•

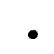

•

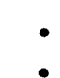

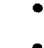

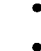

.

$\dot{*}$

$\bullet$

$\bullet$

$\bullet$

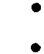

.

6.22

7.58

4.80

4.95

6.20

9.30

10.40

10.20

7.10

4.38

4.17

4.66

5.74

5.87

6.72

5.34

7.70

7.75
British

Series

8.72

8.92

8.84

7.61

6.61

6.32

7.04

6.82

8.52

10.64

7.12

6.30

6.30

5.90

6.10

8.20

9.03

9.07

7.72

6.84

5.77

6.40

7.57

7.80

7.30

6.97

6.76

6.27

6.08

5.92

5.93

5.75

5.70

5.88

6.53 


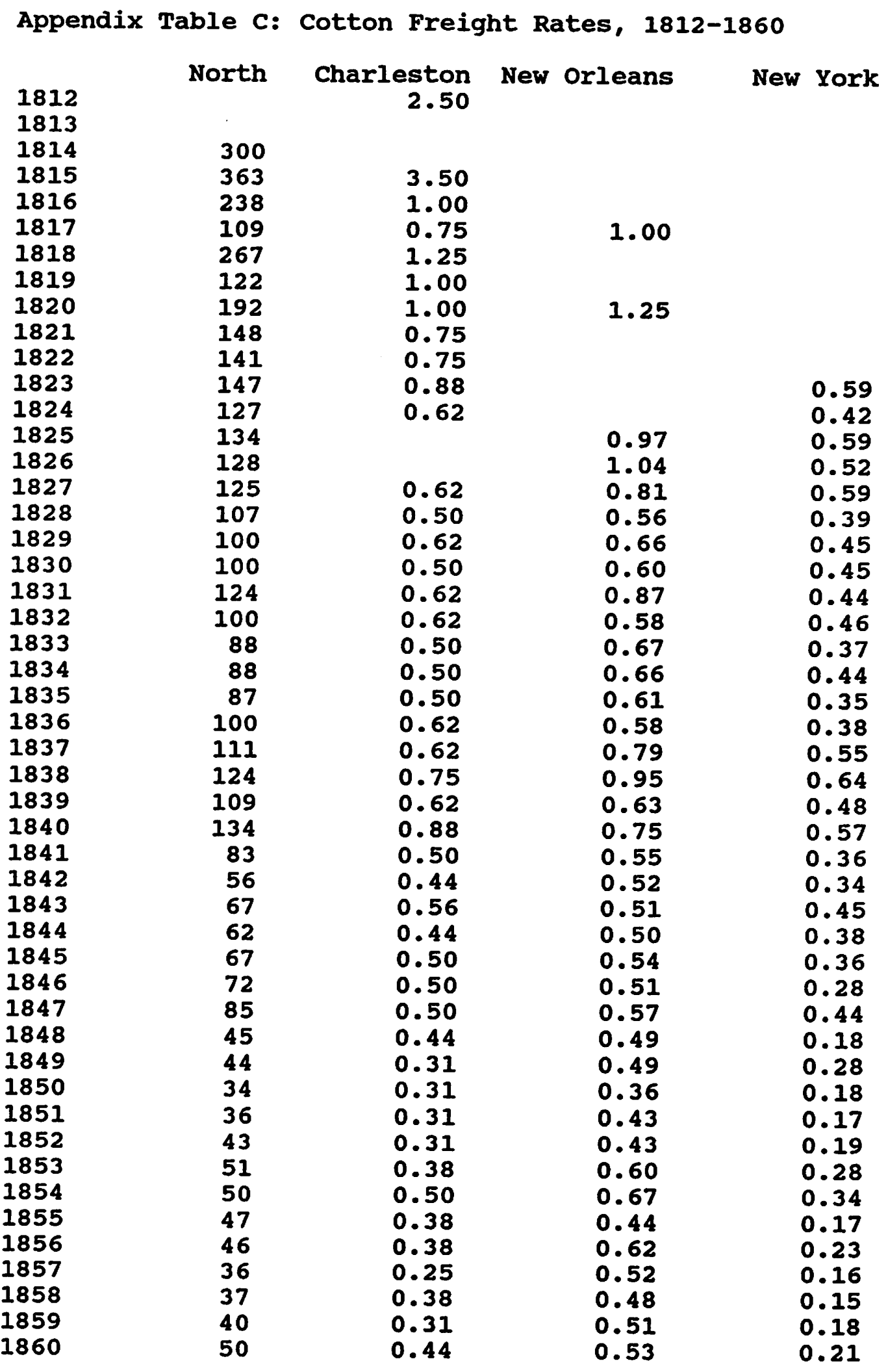

